Arleta SuWALSKA

ORCID 0000-0003-0713-8451

Uniwersytet Łódzki

\title{
THE LAST EDUCATIONAL CHANGE IN FINLAND - ITS DIMENSIONS AND MULTILITERACY TEACHING
}

\begin{abstract}
Aвstract. Suwalska Arleta, The Last Educational Change in Finland - its Dimensions and Multiliteracy Teaching [Ostatnia zmiana edukacyjna w Finlandii - jej zakres i nauczanie wielostronnej alfabetyzacji]. Studia Edukacyjne nr 60, 2021, Poznań 2021, pp. 199-211. Adam Mickiewicz University Press. ISSN 1233-6688. DOI: $10.14746 /$ se.2021.60.11
\end{abstract}

This article reveals the educational change in Finland in the context of multiliteracy. Multiliteracy is one of the seven transversal competences introduced by the Finnish basic education curriculum reform between the years 2012 and 2016. School multiliteracy is developed through cross-subject studies with the usage of particular language. There are involved various texts during teaching to prepare well-educated global citizens who are able to to overcome obstacles of the contemporary world and to follow the global changes in a job market. Multiliteracy helps prepare a global citizen with the skills of global lingua franca.

Key words: multiliteracy, transversal competences, cross-subject teaching, multidisciplinary learning, educational change

Change is made visible, discussable, and operable, both in the case of fast and dramatic turns or slower and less noticeable changes that have more profound impacts. Change has a dialectical connection to the hopes, dreams, and fears of different operators in the socjety. T. Airaksinen, I. Halinen, H. Linturi ${ }^{1}$

\section{Introduction}

The world around us is rapidly changing and as a result the school is obliged to change, too. Every teacher should understand the changes which result

${ }^{1}$ T. Airaksinen, I. Halinen, H. Linturi, Futuribles of learning 2030 - Delphi supports the reform of the core curricula in Finland, European Journal of Futures Research, 2017, p. 2. 
from reform and the legitimacy of their implementation in the educational institution. ${ }^{2}$ In this light, I would like to answer for the qustions Does education help us face the challenges of the future? What kind of future does education construct? ${ }^{3}$ What is the passport of a global citizen? Is it a global lingua franca?

In this article, there will be presented the most difficult challenges that have had teachers due to the change of their way of thinking and quite often way of bahaving, too. I would like to pay special attention to ways how teachers introduce this educational change in context of multiliteracy, which is a skill needed to interpret, produce and assess varied forms of text. It is one of the seven transversal competences introduced by the Finnish basic education curriculum developed through cross-subject studies with the usage of particular language.

In the perspective of policymakers education should give individuals the knowledge and tools to realise their professional and personal objectives in life. ${ }^{4} \mathrm{On}$ the other side, citizens must be sure that the national organisations have enough skills and talents to encompass government of the particular country with its economy and society to accomplish their goals. In Worldwide Educating for the future index 2018 Finland is an undisputed leader.

Table 1

Worldwide Educating for the future index $2018^{5}$

\begin{tabular}{|c|l|c|c|c|c|}
\hline Rank & Economy & $\begin{array}{c}\text { Overall } \\
\text { Score }\end{array}$ & $\begin{array}{c}\text { Policy } \\
\text { Environment }\end{array}$ & $\begin{array}{c}\text { Teaching } \\
\text { Environment }\end{array}$ & $\begin{array}{c}\text { Socio-Economic } \\
\text { Environment }\end{array}$ \\
\hline 1 & Finland & 80,9 & 96,7 & 67,6 & 90,6 \\
\hline 2 & Switzerland & 80,3 & 93,6 & 69,5 & 87,6 \\
\hline 3 & New Zealand & 79,3 & 88,2 & 69,7 & 90,1 \\
\hline 4 & Sweden & 78,1 & 89,5 & 66,5 & 89,8 \\
\hline 5 & Canada & 77,9 & 76,5 & 74,5 & 88,3 \\
\hline 6 & Netherlands & 76 & 71 & 75,4 & 85,1 \\
\hline 7 & Germany & 74,8 & 77,4 & 69,7 & 83,8 \\
\hline 8 & Singapore & 74,8 & 94 & 66,9 & 65,7 \\
\hline 9 & France & 74,2 & 83,4 & 67,1 & 77,9 \\
\hline
\end{tabular}

Having the highest score in the world in the socio-economic and policy environment Finland has created the third position in teaching environment, too. In this light we follow the statement that the key to success are policy-

\footnotetext{
${ }^{2}$ A. Suwalska, English Educational Policy, Contemporary Challenges in a Historical-Comparative Context, Łodź - Kraków 2017, p. 13.

3 T. Airaksinen, L. Halinen, H. Linturi, Futuribles of learning 2030, p. 2.

${ }^{4}$ Worldwide Educating for the future index 2018, Building tomorrow's global citizens, 2018. Retrieved from:https://educatingforthefuture.economist.com/EIUYidanPrizeEducating FortheFuture2018WP.pdf?fbclid=IwAR1S8w0DOJte7aG-wY2sZoLBzRyyDFLZZeRA2 fTcBSHVMVoVXQyQmGn4lJk, [accessed: March 24, 2019], p. 24.

${ }^{5}$ Ibidem, p. 6.
} 
makers who are mostly responsible for the right course of the Finnish education. Moreover, according to index they accurately prioritise the future skills needed for their citizens.In this group there were also included beside Finland five economies like Canada, Chile, New Zealand, Singapure and Sweden. All they got the perfect marks for the coverage and importance their national education strategy affords 21-st century skills. ${ }^{6}$

On the other side, the authors of the Worldwide Educating for the future index 2018 mentioned that the first step to meet success was to articulate future-skills objectives. It must be done with the support of curriculum. The authors put an emphasis on the schools approach in which students are able to self-direct their learning and solve problems. Only, four countries achieved these frameworks- Finland, Switzerland, Singapore and Sweden.

\section{The changes in teaching in Finland}

It seems that Finland follows the understanding that challenges that teachers are facing today are visible. Teachers cannot teach only like lecturers sitting in front of the classroom and students sit, too. The are obliged to facilitate the group work. These new methods of work includes students' project work and students' creative set of tools to tackle real-life problems. ${ }^{7}$ If the young people career paths are related to constant learning it means that teachers have to face the same demands. Teachers are directed to study how to lead non-class activities at the highest level.

In presented light it is worth to mention that Finland has decided to stay against the Global Education Reform Movement with its consequences for students and teachers. Key principles of the reform include inclusive education, deep and active, multifaceted and cross-subject learning. In Finland there were asked questions: What knowledge, skills, attitudes and values will todays students need to thrive and shape their world? How can instructional systems develop these knowledge, skills, attitudes and values effectively? ${ }^{8}$

As a result, Finns do not follow the standardization, test-based accountability and constant teaching-learning process control. Finland follows the globally oriented values and skills. According to Worldwide Educating for the future index 2018, almost in all countries there are mentioned in the index such skills like foreign languages, civic awareness and global citizenship skills. ${ }^{9}$

\footnotetext{
${ }^{6}$ Ibidem, p. 10.

${ }^{7}$ Ibidem, p. 15.

8 The Future of Education and Skills 2030 project, Retrieved from: https://www.oecd.org/ education/2030/E2030\%20Position\%20Paper\%20pdf, [accessed: March 20, 2019], p. 3.

${ }^{9}$ Worldwide Educating for the future index 2018, p. 24.
} 
The country has widely analyses the competences needed in Finnish future society. The National Core for Basic Education describes the concept of transversal competences which are closely related to knowledge, values, attitudes and will. These areas include:

- Thinking skills and learning to learn,

- Taking care of oneself and others, managing daily activities, safety,

- Cultural competence, interaction and expression,

- Multiliteracy,

- ICT-competence

- Working life and enterpreneurial competence,

- Participation, influence and building a sustainable future. ${ }^{10}$

As a result, the local providers of education (municipalities) and local teachers work on the local curriculum. Moreover, local providers of education not only collect tax money, but they decide about allocations of collected money into schools, too. Furthermore, this decentralised education system is responsible for equal opportunities for all students. Consequently there are prepared national level, long-term strategic aims which must be established and local level plans, such as a curriculum and an equity plan, must be prepared and implemented. ${ }^{11}$

On the other side, in 2014 there was established in Finland th FINEEC, which is an independent government agency and is responsible for the country's evaluation of education. The FINEEC evaluate, assess and conducts quality assurance activities from pre-primary education ( childhood education) till higher education.

\section{The reform of education in Finland}

The Finnish National Agency for Education (FNAE) in autumn 2012 discharged the national core curriculum taking into account main goals not only for pre-primary, but basic education, too. There was used Government's Decree of 2012. In this time there was formed an advisory group to help design the reform efficiently. This group had representatives from ministries, teachers and their union, industrial union, parents and minor ethnic groups. This introductory phase of reform lasted from autumn 2012 till December 2014. Definitly, the Finnish National Agency for Education made the

${ }^{10}$ National Core Curriculum for Basic Education 2014, verkkokauppa.oph.fi/EN/page/ product/national-core-curriculum-for-basic-education-2014/2453039 [access: 30.03.2019].

${ }^{11} \mathrm{~J}$. Lavonen, Governance decentralisation in education: Finnish innovation in education, Revista de Educación a Distancia, 31 Marzo 2017, 53, 1, p. 4-5. 
final decision about the new, national core curriculum for pre-primary and basic education. After that, the same representatives were asked to prepare the core curriculum for upper-secondary education, which was finished in and published in 2015. Moreover, the new core curriculum for early childhood education was published in 2016. The main goal of the reform was to create better prerequisites for successful teaching and for meaningful and enjoyable learning so that students would develop better competences for lifelong learning, active citizenship and sustainable lifestyle. ${ }^{12}$

The FNAE was responsible for the Learning Barometer 2030. This new tool was prepared to the systematic usage in the wide process of curriculum reform. The Learning Barometer used new ways of leading opportunities for particpation, knowledge-sharing, and collaborative design of visons. ${ }^{13}$

The introduced reform was tightly related to the New Skills Agenda for Europe which were launched by European Commission and were one of the priorities of the Commission's work program 2016. The Agenda involved three areas to improve:

1. Basic competences,

2. Visibility and comparability of competences,

3. Labour market and skills intelligence to facilitate effective career decisions in the fields of education, training and (un-)employment. ${ }^{14}$

Moreover, all introduced educational changes are strictly related to promotion of the employability of the individual, social cohesion and the global competitiveness of Europe through the development of human capital, especially as cheap labor is not a competitive advantage for the EU. ${ }^{15}$

\section{Transversal competences with multidisciplinary learning}

Globalized world of 2nd decade of the XXI century introduces a lot of changes. Cross-subject teaching focuses on transversal competences which coexist within school subjects. The usage of competences obliged teachers to reflect them in the aims of each subject.The competences are useful to describe not only knowledge and skills but attitudes and values. The enable students to lead a life full of meanings and to function satsfactorily in society.

${ }^{12}$ T. Airaksinen, L. Halinen, H. Linturi, Futuribles of learning 2030, p. 2.

${ }^{13}$ Ibidem.

${ }^{14}$ New Skills Agenda for Europe: State of implementation, Retrieved from: http:/ /www. europarl.europa.eu/RegData/etudes/BRIE/2017/607334/IPOL_BRI(2017)607334_EN.pdf [accessed: March 16, 2019], p. 1.

${ }^{15}$ Ibidem. 
According to The National Core Curriculum for Basic Education, "the concept of transversal competence refers to an entity consisting of knowledge and skills in a given situation" ( FNBE, 2014, OECD 2015). The development of competences was linked to the concept of learning and the school culture which were described in the Core Curriculum. Finns trust teachers' professional insights and ways of solving school problems. Furthermore, famous Finnish educator, Matti Koskennniemi, used the term "pedagogical love". ${ }^{16}$

The Government decree from 2012 presented "the allocations of lessons hours which is prepared to each school subject", whereas the Basic Education Act had organized the school subjects for students in basic education.

\section{Literacy and its different dimensions in Finnish education}

Competences, which are part of 21st skills according to OECD (2005) Definition and Selction of Competences, are important to study at schools. In Finland teachers should pay attention to the ways how they teach transversal competences through different subjects, but do not neglect the subjects. It makes sense to admire teachers in Finland, who are able to combine, during the same time, teaching the particular subject with teaching multiliteracy.

The Finnish remedy how to solve the arising problems is simple. Finns are involved in the aims of particular subjects not only indispinsable subject elements but first of all the needed elements to be developed through transversal competences. This simple way of teaching proves that the transversal competence is being taught and consequently studied by Finnish students.

On the other side, in Finland each transversal competence is always presented not only in teaching points of all subjects, but in learning points, too. To understand how multiliteracy is embodded in each subject it is significant to find out what are the contents of each subject. The National Core Curriculum has been based on the concept of learning and its vision depend on students who are active participants of learning.

In presented light, students study how to set possible goals and they try, step by step, to find out their own solutions. Students can study alone (independently) or in groups (collaboration work). It is important to mention that concept of learning on which competences are taught is based on interaction between pupils, teachers and quite often various communities. Students who study together in collaboration are more creative. Furthermore, learning in collaboration, immediately influences on their critical thinking and prob-

${ }^{16}$ A. Suwalska, Culture of teaching in Finnish schools in context of educational change, Polish Journal of Educational Studies, 2018, I LXXI, p. 114. 
lem-solving skills. Teaching is in these circumstances is led according to students' different styles of learning and their different preferences.

Students' work is related to the new skills and knowledge acquisition. Moreover, students experience positive emotions which reinforce their joy of learning. As a result of above mention factors, students' motivation to study directly influences on their eagerness to develop multiliteracy as a competence. Consequently students awareness of their personal preferable styles of learning is increasing and they understand subject of study deeper and better. They learning knowledge is practically anchored in their minds. They are not against tedious activities and long hours of work.

\section{How important is to improve and enhance teachers' multiliteracy awareness}

Multiliteracies are part of well tailored mission of education which purpose is to gain knowledge from learning. As a result students are be able to participate fully in life at public, social and economic levels. In this light, literacy pedagogy plays a significant rule to prepare full and equitable conditions to fulfill it.

Multiliteracies or "many literacies" is a term introduced by a group of literacy scholars from the United States, Great Britain, and Australia called the New London Group (1996) - rest on the belief that literacy is socially constructed and dynamic in nature. According to the New London Group, mulitiliteracies have emerged as a result of new communications and an increasingly global culture in which cultural and linguistic diversity is more and more the norm ${ }^{17}$ (The New London Group, 1996, p. 64).

Multiliteracies are diffent in countries. They differ according to culture and context, and have specific cognitive, cultural, and social effects (ibidem, p. 64). Multiliteracies present a complex phenomena. Moreover, multi and alternative literacies can enrich the forms of reading and writing by using multidimensional and richer in context environment to write the text. As a result, students can practise the same topics from different perspectives. Furthermore, pupils use many alternative literacies of written texts like instant messaging and emoticons which not only extend their knowledge about contemporary textual writing forms but employ the new modalities, too.

Multiliteracy describes facts about the rapidly changing social and technological contexts of learning. It asks the question how we should constitute the suitable literacy pedagogy for XXI century? In the presented perspective of

${ }_{17}$ E.F. Provenzo et al., Multiliteracies. Beyond Text and the Written Word, Information Age Publishing USA 2011, p. XX; Z. Bauman, Płynne życie, przekł. T. Kunz, Kraków 2007, p. 8. 
change there is need to force teachers' language awareness and their knowledge about multiliteracy factors. It is needed to involve teachers into familiarising of texts, genres and languages through teachers' meeting with free and supportive materials. ${ }^{18}$

\section{Goals of multiliteracy in Finnish basic education}

The core ideas which were introduced with Basic Education Curriculum depend on active learners with integrative teaching. Moreover, sustainable way of living in Finland was possible through comprehensive education in schools as learning communities. To make it possible there was created the ethos of trust to teachers' job in schools. It was linked to the highest professionalism of teachers and supportive ethos of good student-teachers relationships at schools. Furtermore, students were encouraged to be active during lessons and to find out the individual approach to studying.

Multiliteracy, which involves many types of lieracies, creates the opportunities to students to improve their learning environments with technological, full of media backgrounds. Literacy is strongly connected to a person's self-development and involvement in society through the ability to understand, analyse and utilise texts. It is not merely the mechanistic recognition of words and phrases, but the combination of skills and social practices in order to understand the world and other people. ${ }^{19}$

Literacy, which is seen as a basic skill, in the contemporary world is accessed by visual and numerical digital text with audio. In Finland reading was perceived as the main free time activity in the past. Multiliteracy teaching can contribute to the raising tendency in reading among students and teenagers. It is especially significant in time when students choose shorter text and do not like reading long texts.

Finnish ninth-graders are still among top readers in the world, but the level of literacy is decreasing. (...) Texts with diverse modes of expression are usedas learning materials, and the pupils are supported in understanding their cultural contexts.The pupils examine authentic texts that are meaningful to them and interpretations ofthe world that arise from these texts. ${ }^{20}$

The Core Curriculum for Pre-primary Education published in 2014 took into consideration not only the culture of work in Finnish schools, but first of

${ }^{18}$ E.F. Provenzo et al., Multiliteracies. Beyond Text and the Written Word, p. XV.

${ }^{19}$ I. Halinen, M. Harmanen, P. Mattila, Making Sense of Complexity of the World Today: why Finland is Introducing Multiliteracy in Teaching and Learning, 2015, Retrieved from: www.oph.fi/ download/173262_cidree_yb_2015_halinen_harmanen_mattila.pdf, [accessed: March 16, 2019], p. 143.

${ }^{20}$ Ibidem. 
all the learning environment of each child. It enables easily monitor and cooperate pre-primary nad basic education. Moreover, at pre-primary level multiliteracy must be reinforced by wide cooperation with guardians. Multiliteracy is presented as a new concept. The development of multiliteracy begins already in early childhood and continues throughout one's life. ${ }^{21}$

\section{Multiliteracy in grades 1-2}

Multiliteracy has been encorporated and widely developed during all subjects in Finnish schools since 2014. There were created by teachers good conditions to work in varied textual environment. To fulfill this dream teachers cooperate to each other and prepare lessons including varied, rich and meaningful texts to help students interpret the surrounding world. This allows pupils to rely on their strenghths and utilise contents that engage them in learning, and also draw on them for participation and involvement. ${ }^{22}$

According to Halinen I., at all, 2015, the texts suitable at grades 1-2 include newspapers, books, games and movies. They mentioned about students own production of movies, simple books and games. In such created activities students acquire different and varied ways of expressing the surrounding world. Moreover, they experience so many opportunities in which they naturally ask questions about wonders of the world, tell stories, state their views and share their experiences using many types of tools and means of expression. ${ }^{23}$

\section{Grades 3-6 -multiliteracy}

As the students are getting older and older the texts, used during lessons where multiliteracy is introduced, are increasing in the level of difficulty. The texts present fictional and non-fictional heroes and encourage students to argumentate their points of views. Teachers's rule is to guide students' observations and interpretations of varied texts to influnce on their choice of interpretation and expression.

A this level students are anchored in informative, entertaining and every day texts. The analysed texts are getting more advanced due to their interpretations according to the author's and audience points of view. The range of

21 Ibidem.

${ }^{22}$ K.Kivinen,National CoreCurriculumforBasicEducation Emultiliteracy complilation(https:/ / kivinen.files.wordpress.com/2017/02/finnish- national-core-curriculum-multiliteracy.pdf, 2016, [access: 30.03.2019], p. 1.

23 I. Halinen, M. Harmanen, P. Mattila, Making Sense of Complexity of the World Today, p. 141. 
used texts is more varied, too. There are used not only orally, audivisully and digitally prepared materials, but there are incorporated library services, too. The meanings of materials are reinforced by wide variety of media.

The critical literacy sources of information are enriched by decsriptive, narrative and full of comparisons and comments texts prepared by teachers. As Irmeli Halinen (2015) suggests the development of multiliteracy at this level should be reinforced by active reading and students' own production of various types of texts. To sum up, the main objectives of multiliteracy seems to be pupils encouragement to practise skills and to be members of democtratic society. Moreover, to be able to participate in the activities of different communities and to practise using the media safely and with social awareness. ${ }^{24}$

\section{Multiliteracy in grades 7-9}

Students at this level are taught to expand their multiliteracy skills at all school subjects in Finland. As a result, they got information full of verbal, visual and numerical symbols. Moreover, there is introduced not only analitical and cultural literacy, there is reinforced critical literacy, too.

Production, communication and interpretation of varied texts is cooperativelly incorporated through cross-subject teaching by different subject teachers. Futhermore, students' multiliteracy is is strengthened by the media and the society around them. To make it more useful, students are learned visual literacy by different ways or so called modes of image interpretation and presentation..$^{25}$

\section{Mother tongue in Finland}

It is worth to mention that multipurpose opportunities for using varsatile texts are the key to success in teaching mother tongue in Finland. It is significant to teachers to lead guidelines to enlarge analytical and critical literacy skills of students. Moreover, there is need to practise ability to find out issues taking into consideration variety of sources of information. The most important seems to be to identify the key stages of information acquisition and knows where and how to search and that the pupil would be able to evaluate the usability and reliability of sources. ${ }^{26}$

${ }^{24}$ National Core Curriculum for Basic Education 2014, Retrieved from: verkkokauppa. oph.fi/EN/page/product/national-core-curriculum-for-basic-education-2014/2453039 [accessed: 30.03.19].

${ }^{25}$ Ibidem.

${ }^{26}$ Ibidem. 


\section{History, Social Studies and multiliteracy}

The aim of teaching is to pay attention of students' to critical information and the ability to analyse it. It is important to find out premise of history in context of the past perception. Moreover, the aim is to develop the textual skills, especially important for history. It seems obligatory to guide the students' ability to interpret and understand the written texts in a historical context. Furthermore, it is not rare to focus students' attention on original political texts to understand better and wider political tensions, phenomena and problems of the contemporary world.

The main tasks of social studies teaching include support the development of students competences in enerpreneurship. Moreover, students acquire needed skills to become economically and socially active citizens.

In grades 7-9 students make the social decisions and are partly involved in the school community. The are able to compare their opinions and believes from the perspective of different life values and societal groups. Furtheremore, they practise economic issues and international relationships in context of global changes.

\section{Subject teaching and multiliteracy}

It also makes sense to mention about multiliteracy teaching during the other subject teaching (geography, physics, religion, health education, music). Multiliteracy is incorporated into map reading and understanding them. Moreover, it helps to cope with symbols, proportions, directions and distances (National Core Curriculum for Basic Education 2014). Multiliteracy during physics teaching is needed to be able to produce scientific, detailed information which varies physical views. Furthemore, during religion lessons multiliteracy helps support the argumentation and different religion's viewpoints. Health education helps understand how to stay physically, mentally and socially healthy. Music lessons guide students' to use the different styles, teminologies and concepts of music.

\section{Languages and multiliteracy}

In 2004 the new Core Curriculum in Finland involved openning text about Sami language background, the text about Romani, the signed language and the texts about students from immigrant backgrounds. The new Core Curriculum in Finland 2014 introduced and explained language awareness and in 
this light it presented different languages and cultures. Moreover, the main task of basic education is to promote among students the value of different languages and cultures with immediate promotion of bi- and plurilingualism. As a results, it seems indispinsable to reinforce pupils' language awareness and to build up their metalinguistic skills. In a liguistically consious school teachers are foreign language models.

Furthermore, in Finland every school teaches students' different languages and creates its own pluringual school culture. The practice of everyday life at school means the identity of students and their reality (provides them with signs, giving them meaning). ${ }^{27}$ As a result schools, which created linguistically aware school cultures, allow multiliteracy to be developed at the highest level. Languages and cultural awareness can now be encountered as parts of the task of basic education, the value base, school culture, transversal competences and more. Together with cultural diversity, language awareness is seen to constitute one of the seven pillars or core aspects of school culture. ${ }^{28}$ In this rich and varied linguistic diversity students develop their skills. They are able to read about results of different scientific disciplines.

\section{Conclusion}

This article presented the educational change in Finland in the context of multiliteracy. Multiliteracy is one of the seven transversal competences introduced by the Finnish basic education curriculum reform between the years 2012 and 2016. Multiliteracy seems indispinsable competence in the 21 st century to interpret, produce and assess varied forms of text. It follows the global changes in a job market and helps prepare a global citizen with the skills of global lingua franca. The various texts are needed to face the challenges of the future. School multiliteracy is developed through cross-subject studies with the usage of particular language.

Moreover, from Polish perspective it is needed to follow and analyze the practical aspect of reforms in Finland to be able to introduce them into Polish educational system. Finland has built the standard itself to which other countries could aspire. ${ }^{29}$

It is undisputed that Finnish teachers follow the same values about vision of education and they set up their work in a cooperative way. As a result, teachers in Finland prepare thoughtful global citizens who are able to overcome obstacles of the contemporary world.

27 Z. Melosik, T. Szkudlarek, Kultura, tożsamość i edukacja - migotanie znaczeń, Kraków 2013, p. 18.

${ }^{28}$ I. Halinen, M. Harmanen, P. Mattila, Making Sense of Complexity of the World Today, p. 148.

${ }_{29}$ T. Gmerek, Społeczne funkcje szkolnictwa w Finlandii, Poznań - Leszno 2007, p. 207. 


\section{BIBLIOGRAPHY}

Airaksinen T., Halinen I., Linturi H., Futuribles of learning 2030 - Delphi supports the reform of the core curricula in Finland, European Journal of Futures Research, 2017, 5 [access: 20.03.2019].

Bauman Z., Płynne życie, przekł. T. Kunz, Wydawnictwo Literackie, Kraków 2007.

Gmerek T., Społeczne funkcje szkolnictwa w Finlandii, Drukarnia HAF Leszno, Poznań Leszno 2007.

HalinenI.,Harmanen M.,MattilaP.,Making SenseofComplexityoftheWorld Today:why Finlandis Introducing Multiliteracy in Teaching and Learning, 2015, www.oph.fi/download/173262 cidree_yb_2015_halinen_harmanen_mattila.pdf, [access: 20.03.2019].

Kivinen K., National Core Curriculum for Basic Education \& multiliteracy complilation (https:/ / kivinen.files.wordpress.com/2017/02/finnish- national-core-curriculum-multiliteracy.pdf, 2016, [access: 30.03.2019].

Lavonen J., Governance decentralisation in education: Finnish innovation in education, Revista de Educación a Distancia, 31 Marzo 2017, 53, 1.

Melosik Z., Szkudlarek T., Kultura, tożsamość i edukacja - migotanie znaczeń, Oficyna Wydawnicza Impuls, Kraków 2013.

National Core Curriculum for Basic Education 2014, verkkokauppa.oph.fi/EN/page/product/national-core-curriculum-for-basic-education-2014/2453039 [access: 30.03.2019].

NewSkillsAgendaforEurope,Stateofimplementation,http:/ / www.europarl.europa.eu/Reg Data/etudes/BRIE/2017/607334/IPOL_BRI(2017)607334_EN.pdf [access:16.03.2019].

Provenzo E.F., Goodwin A., Lipsky A., Sharpe S., Multiliteracies. Beyond Text and the Written Word, Information Age Publishing USA 2011.

Suwalska A., Culture of teaching in Finnish schools in context of educational change, Polish Journal of Educational Studies, 2018, I LXXI.

Suwalska A., English Educational Policy, Contemporary Challenges in a Historical-Comparative Context, Wydawnictwo Uniwersytetu Łódzkiego, Jagiellonian University Press, Łodź - Kraków 2017.

The Future of Education and Skills 2030 project, https://www.oecd.org/education/2030/ E2030\%20Position\%20Paper\%20pdf, [access: 20.03.2019].

The New London Group, A pedagogy of multilieteracies: designing social futures, Harvard Educational Review, April 1996, 66, 1.

Worldwide Educating for the future index 2018, Building tomorrow's global citizens, 2018, https://educatingforthefuture.economist.com/EIUYidanPrizeEducatingForthe Future2018WP.pdf?fbclid=IwAR1S8w0DOJte7aG-wY2sZoLBzRyyDFLZZeRA2f TcBSHVMVoVXQyQmGn4lJk, [access: 24.03.2019]. 